HUDRON K. KARI,

Federal University (Otuoke, Bayelsa State, Nigeria)

e-mail: karih@fuotuoke.edu.ng, ORCID 0000-0001-7475-5172

GBOYEGA K. OYENIRAN,

Federal University (Otuoke, Bayelsa State, Nigeria)

e-mail: karih@fuotuoke.edu.ng, ORCID 0000-0003-0333-8202

\title{
PROMOTING LIBRARY SERVICES IN THE SOCIAL MEDIA ERA: EXPLORING USE, OBJECTIVES, CHALLENGES AND PERCEIVED INFLUENCE
}

The social media have significantly changed almost every part of our being. They have changed the shape and nature of communication. Before the emergence of social media platforms, communication was mainly face-to-face as distance was an essential barrier in communication engagement, but that has changed with the emergence of social media platforms. In addition, library services are also experiencing serious changes as a result of the emergence of social media platforms. This is because services that were once rendered in library halls can now be rendered outside of library building. Library users also have new expectations from library managements. They desire to have services rendered to them in a simple and technologicalbased manner than before. These changes have made researchers interested in examining issues related to changes that have taken place in library management in the social media era. This study examined the use of mediated platforms for creating awareness regarding the services in libraries in Nigeria. The study was guided by five objectives. Descriptive survey was used as the design of the study. Both librarians $(n=300)$ and library users $(n=300)$ were sampled for the study. The questionnaire served as the instrument for data collection. Descriptive analysis like simple percentages, mean and standard deviation were used for the study. It was found that there is low extent of application of social media for the purposes of increasing public awareness of services in libraries. Also, seven objectives of applying social media to enhance awareness of services in libraries were found. Seven strategies for using social media to promote library services were also reported. Six obstacles to the use of social media to promote library services were also reported. They are: lack of skilful manpower; inadequate finance; lack of interest on the part of library management; lack of appropriate and up to date tool; inadequate staff members and lack of a conducive working environment. The perceived influence of exposure to social media messages promoting library services were also reported. The results of this study have implications on library practice and scholarship. Regarding library practice, the results suggests that to effectively promote library services with a corresponding possibility for increased patronage, there is the need for management of libraries to address serious issues of inadequate manpower, lack of facilities and poor funding. When this is done, it is hoped that social media could be fully applied for the purposes of promoting library services in Nigeria. In terms of scholarship, the results of the study has added to the body of literature regarding the important role that social media platforms are now playing in different spheres of the society. In particular, the results has added to studies on the role of social media in library services. It is therefore, recommended that library management should put in place programs and policies that support the use of social media to promote library services. Based on the results of the study, the researchers recommends, among others, the utilization of social media to promote library services. Other recommendations are also made.

Keywords: library services; professional; promotion; social media; users.

\section{Introduction}

Promoting library services is one of the problems that libraries face. This is largely because of two factors. First, library services are like products. They may not be useful until information about them get to the final users with a corresponding possibility for usage. What this means is that no matter how good library services are, usage is a critical requirement to achieve the overall aim of such services. Patil and Pradhan (2014) corroborate that the same way that marketing of products in companies is essential is to increase create awareness and improve on sales as well as market share, the promotion of library services is needed to enhance public knowledge of library services. In the second place, libraries now face new challenges of low library patronage as a result of new technologies. Library users now have different demands 
and expectations from libraries have changed even as recent as ten years ago. There is not possibility that we have seen the last in changes regarding communication technologies. Mitra (2016) opines that the world is now largely an information and communication entertainment in which case people express preference for speedy, and technology driven approach to almost everything and libraries cannot afford to be left behind. Mitra adds that both e-learners and their traditional counterparts can access libraries using Internet facilities. Evidence in literature (Helinsky, 2008; Webreck \& Alman, 2007) also suggest that the digital age has posed a serious challenge to academic libraries which include the utilization of new technologies, budget reduction, the dynamic internal and external environments, as well as new quest of research and teaching. Helinsky (2008) aver that promotion of library facilities is one of the ways through which libraries can meet up with the challenges.

To promote library services is to create awareness on the existing of such services. Scholars (de Saez, 2002; Potter, 2012; Rowley, 2003; Welch, 2006) are of the view that promoting library services also entails having complete knowledge of users' needs and expectations, ascertaining market niches, coming up with products and services that appease to users, developing client relationships and creating 'marketing mix'. The overall aim is to carry the users along as much as possible. Welch (2006) says that libraries and information agencies pay close attention to their clients. They have to understand them very well so as to effectively serve them. Rowley (2003) posits that services are the abstract products that libraries use to compete favourably. The decision a person makes to visit a departmental library instead the university library could be influenced by the quality of services rendered in both libraries. Patil and Pradhan (2014) aver that the objective of library promotion services is to: market services and raise money for libraries, promote the utilization of available reading material in the library and create awareness among the users; improve the image of the library and optimize the use of information within limited resources and manpower.

One of the important decisions that libraries have to make is the choice of promotional tools. This is because wrong choice of promotional tool may hamper the attainment of promotional objectives. Scholars (Fisher \& Pride, 2006; Mathews, 2009; Webreck Alman, 2007) list promotional tools to include digital media, like e-mail lists, print materials, blogs and podcasts, social media, the library's Website, among others. One of the determinants of which promotional tool to use is how effective the tool is in creating awareness about library services. Another consideration is how popular a promotional tool is among library users. Popularity is important because it is one way to guarantee that users will be exposed to promotions on library services. The popularity and acceptance of social media makes it imperative to examine how it could be used for the promotion of library services.

Social media describe Internet-powered communication tools that allow for instantaneous exchange of ideas. Social media platforms allow people to send and receive information (Walter \& Riviera, 2004). Social media also comprises of activities that involve socializing and networking online by means of pictures, words and videos (Nwazor \& Godwin-Maduike, 2015: 127). In the views of Nwazor and Godwin-Maduike (2015: 127), the presence of Internet features, most of whom are of high capacity in terms of speed, make the use of social media common and easy. The increase acceptance and use of smartphones have also made the use of social media a lot easier. Most of the smartphones are very sophisticated with capacity to execute complex tasks.

In a different light, Kaplan and Haenlein (2010) define social media as a collection of communication platforms that depend largely on internet applications to function. They add that social media also make use of Web 2.0 application for allows for interaction among social media users. The activities that take place depends on mobile and web-based technologies to create highly interactive platforms through which individuals and communities share, co-create, discuss and modify user-generated content (Nwazor \& Godwin-Maduike, 2015: 127). Similarly, some of the platform that help users to network include; Facebook, Google+, Hi5, Friendster, LinkedIn, Meerkat, MyLife, Ning, Periscope, Plaxo, Twitter and XING. Others that help in ideas or business promotion include; Bing, Blogging platform Discussion Boards and Forums, Google, Flickr, MySpace, Yahoo, YouTube among several others. Social media platforms are now very popular among different people. Most educated people have access to one social media account or the other. People are spending time on social media now, perhaps, more than they read newspapers and watch TV or even listen to radio. Mathews and George (2013) corroborate that social media have emerged over the past years as common and cheap way of meaning sharing and information exchange. Mathews and George add that social media platforms have advanced from a niche to a mass online engagement with a huge participation. People are accessing social media in different places like churches, in vehicles, lecture hall, at board meetings, in the toilet, at home, in offices, at restaurants, among others. This makes the social media effective for the promotion of library services.

Over the years, scholars have examined the promotion of library services. Nkanga (2002: 309) conducted a study and reported that promotional strategies like telephone calls, memos, circulars, personal contacts, library tours, leaflets, mailing, displays, meetings, direct, talks and newsletters, were widely deployed to create awareness concerning library services. Cummings (1994) carried out a study to examine how libraries are promoting their services and the influence such promotions have on users. The results showed that strategies like, holding lectures, changing library exhibits, combination of outreach programs, classroom instruction and library tours (see also Dodsworth, 1998: 321-332). Jackson (2001: 46) investigated how to promote the interfaces, how to decide the appropriate time to promote the service, and reported that various promotional approaches like leaflets, business cards, newsletters, e-mails, letters, phone calls, contact were applied to get the attention of users. Ashcroft (2002) studied the promotion and assessment of library services and reported that the need to create awareness on the existence of library services as well as the materials available is essential. In other words, users need to know the services that libraries render and the range of materials they have in stock.

Bhat (1998) studied the promotional tactics of the British Council Network in India and reported that strategies such as presentation at institutions, mailouts, personal visits, cultivating the press, brochures, leaflets, extension activities newsletters as well as the placement of advertisement in the media regarding library services available. The researcher did not expand his study to include the use of social media. 
Adeloye (2003: 17) studied different practical ideas such as the application of promotional techniques including library guides brochures, and exhibitions. The Internet was deplored to promote library services and the approaches applied to promote library Website were live digital reference desk, circulation expire alert, cross search and library portals (Ju, 2006: 341-342). In contemporary society with new communication technologies coming up almost every day, librarians deploy some software and hardware applications like wikis and podcasting, media-sharing tools such as YouTube and Flickr, and social networking services such as Twitter and Facebook as well as blogs to assist them in rendering services to the general public (Hinchliffe \& Leon, 2011; Moulaison and Corrado, 2011; Yi, 2014). However, studies, especially from perspective have not significantly examined the application of social media in promoting library services. Therefore, this study sought to achieve five objectives: to ascertain the extent of use of social media for promoting library services; to determined the objective of using social media for promoting library services; to ascertain the strategies for using social media for promoting library services; to ascertain the challenges to use of social media for promoting library services and to ascertain the relationship between exposed to library services on social media and use of library services.

\section{Materials and Method}

The researchers adopted descriptive survey research design to achieve the objectives of the study. We considered survey useful because useful because approach enabled the researchers to describe and explain the use of social media for the promotion of library services with particular attention to Nigeria. A total of 300 librarians and 300 libraries users in Nigeria took part in the study. The librarians were from Federal and state University owned libraries in Nigeria. The library users were undergraduates from Federal University Otueke who took part in the study. The researchers adopted purposive sampling technique to select the library users and the undergraduates who took part in the study. The essence of the sampling process was not to get a representative sample of librarians nor undergraduates, both to recruit persons who had information about the subject matter. The researcher used a self-developed questionnaire as the instrument for data collection. The questionnaire was developed after a review of relevant literature. The response format was multiple option for the demographics and a four point Likert scale for the psychographic response. The instrument sought both demographic and psychographic data of the sample. We used three experts from the Federal University Otueke to validate the questionnaire. The experts were requested to ascertain the clarity of the items, logicality of items and appropriateness. At the end, the corrections from the experts guided the researchers in producing the final copy. To ascertain the reliability of the instrument, the researchers used a test re-test approach. Consequently, earlier 20 copies of the drafted questionnaire were administered to 20 persons in Enugu State. This was repeated after two weeks interval. The correlation coefficient calculation was .77 , an indication of high reliability of the instrument.

The researchers used both descriptive statistics to analyse data for the study. Therefore, descriptive statistics like simple percentages, mean and standard deviation were used to present the average response from data gathered. The benchmark for accepting or rejecting items for the Likert scale was 2.5 .

\section{Results}

There was $95 \%$ return rated for library professionals and $91 \%$ return rate for library users. That is to say that among the 300 copies of the questionnaire administered to librarians, 285 copies were returned and found useful. On the other hand, of the 273 copies of the questionnaire administered to library users were returned and found useful. Overall, the mean percentage return rate for the sample was $93 \%$. The mean age of librarians was 45 (range 33 and 57 years). The mean age of library users was 23 (range 20 and 26). Regarding gender, the library professionals were $75 \%$ male and $25 \%$ female. On the other hand, the library users were $67 \%$ male and $33 \%$ female. The psychographic data is presented below. First, a graph was plotted to ascertain the extent of use of social media for promoting library services.

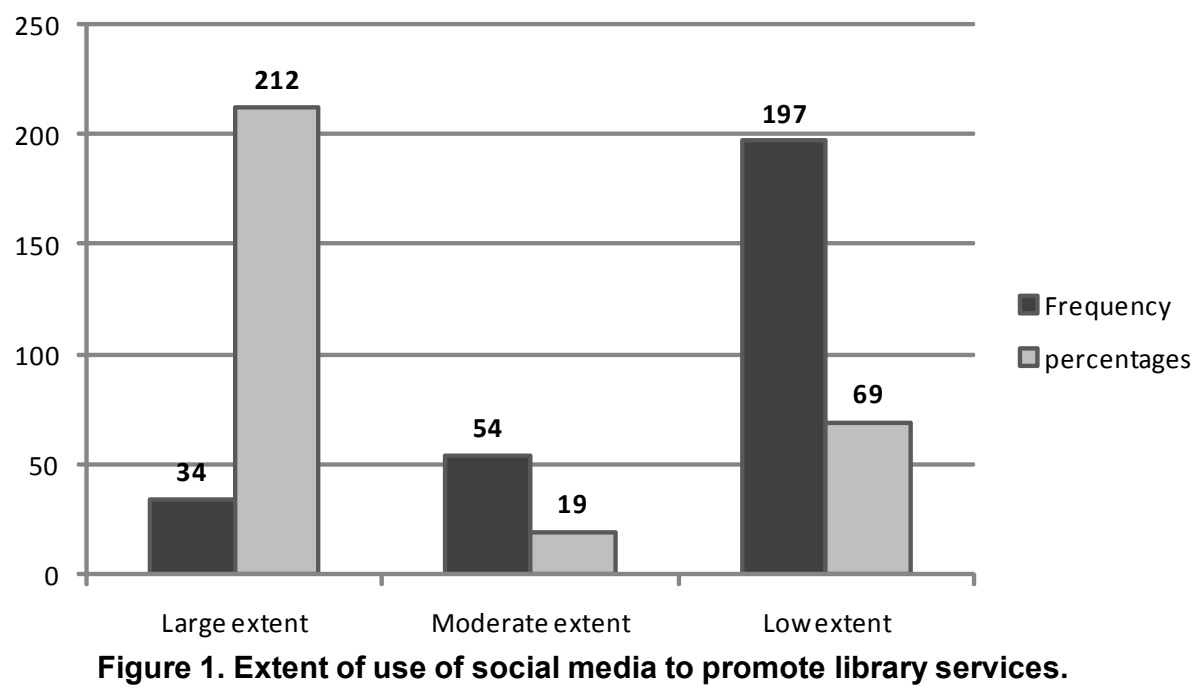

The graph above was plotted to ascertain the extent of use of social media to promote library services. It was found that most of the respondents reported that there is low use of social media to promote library services. This result has negative implications on the promotion of library services because it suggests that libraries in Nigeria are yet to fully harness the benefits that social media platforms offer. 
Table 1: objectives of using social media to promote library services $(n=285)$

\begin{tabular}{llccc}
\hline S/N & Items & Mean & SD & Remark \\
\hline $\mathbf{1}$ & To create awareness on library services & 3.1 & .99 & Accepted \\
$\mathbf{2}$ & To educate users on library services & 2.7 & .98 & Accepted \\
$\mathbf{3}$ & To encourage patronage of library services & 2.8 & .76 & Accepted \\
$\mathbf{4}$ & To meet $21^{\text {st }}$ century library users at their door steps & 3.0 & .71 & Accepted \\
$\mathbf{5}$ & To satisfy the need of library users & 2.9 & .56 & Accepted \\
$\mathbf{6}$ & To outsmart competitors & 2.7 & .68 & Accepted \\
$\mathbf{7}$ & To meet up with the demand of the $21^{\text {st }}$ century library services & 2.6 & .78 & Accepted \\
\hline
\end{tabular}

In table one above, the researcher sought to ascertain the objectives of promoting library services from the point of view of library professionals. It was found that all the items presented were accepted as the objectives that drive the promoting of library services through social media. This is because all the items met the benchmark criterion mean score of 2.5 and above. Comparatively, awareness creation had the highest mean while meeting the demand of the $21^{\text {st }}$ century library services had the least score. In table two, the researcher sought to ascertain the strategies for using social media to promote library services.

Table 2: Strategies for using social media to promote library services $(n=285)$

\begin{tabular}{llccc}
\hline S/N & Items & Mean & SD & Remark \\
\hline $\mathbf{1}$ & Creating dedicated social media accounts on library services & 3.4 & .91 & Accepted \\
$\mathbf{2}$ & Embedding information on library services into the accounts of users. & 2.9 & .67 & Accepted \\
$\mathbf{3}$ & Using multiple social media accounts like Facebook, YouTube, Twitter & 2.6 & .66 & Accepted \\
$\mathbf{4}$ & Using pictures in social media messages on library services & 3.2 & .98 & Accepted \\
$\mathbf{5}$ & Using videos to explain certain aspects of library services & 2.5 & .78 & Accepted \\
$\mathbf{6}$ & Frequently updating social media messages on library services & 2.8 & .90 & Accepted \\
$\mathbf{7}$ & Providing 24 hours 7 days prompt response from users & 3.1 & .67 & Accepted \\
\hline
\end{tabular}

In table two above, the researchers sought to ascertain the strategies for using social media to promote library services. A total of seven items were presented to the respondents and all the items were accepted. This is because the items scored mean values of more than 2.5 which is within the benchmark for accepting or rejecting items. Overall, creating dedicated social media accounts on library services had the highest mean score followed by providing uninterrupted social media interaction with users. To ascertain the challenges to the application of social media for the purposes of promoting library services, table three was computed:

Table 3: Challenges to the use of social media for promoting library services $(n=285)$

\begin{tabular}{llccc}
\hline $\mathbf{S} / \mathbf{N}$ & Items & Mean & SD & Remark \\
\hline $\mathbf{1}$ & Lack of skilful manpower & 2.8 & .81 & Accepted \\
$\mathbf{2}$ & In adequate finance. & 2.7 & .64 & Accepted \\
$\mathbf{3}$ & Apathy on the part of librarians & 2.2 & .68 & Rejected \\
$\mathbf{4}$ & lack of interest on the part of library management & 3.2 & .67 & Accepted \\
$\mathbf{5}$ & Lack of appropriate and up to date tools & 2.5 & .74 & Accepted \\
$\mathbf{6}$ & Inadequate staff members & 2.6 & .91 & Accepted \\
$\mathbf{7}$ & Lack of a conducive working environment & 3.0 & .88 & Accepted \\
\hline
\end{tabular}

The essence of table three above was to find out the challenges to the use of social media for the promotion of library services. The results showed that all but one of the seven items were accepted as the challenges that library professionals face in a bid to use social media to promote library services. The librarians rejected the item regarding their apathy to the use of social media to promote library services. Most of the challenges identified were more related to management of libraries. In table four, the researchers examined the perceived influence the promotion of library services though social media on users.

Table 4: perceived influence the promotion of library services though social media on users $(n=273)$

\begin{tabular}{llccc}
\hline $\mathbf{S} / \mathbf{N}$ & Items & Mean & SD & Remark \\
\hline $\mathbf{1}$ & $\begin{array}{l}\text { Exposure to information on library services on social media will influence my } \\
\text { image of libraries positively }\end{array}$ & 3.3 & .92 & Accepted \\
$\mathbf{2}$ & $\begin{array}{l}\text { Exposure to information on library services on social media will influence my } \\
\text { attitudes towards libraries positively }\end{array}$ & 2.7 & .55 & Accepted \\
$\mathbf{3}$ & $\begin{array}{l}\text { Exposure to information on library services on social media will influence my } \\
\text { use of libraries positively } \\
\text { Exposure to information on library services on social media will influence my } \\
\text { educate me on library services }\end{array}$ & 2.8 & .98 & Accepted \\
$\mathbf{5}$ & $\begin{array}{l}\text { Exposure to information on library services on social media will influence my } \\
\text { competence in using library services. }\end{array}$ & 2.7 & .77 & Accepted \\
$\mathbf{6}$ & $\begin{array}{l}\text { Exposure to information on library services on social media will influence } \\
\text { frequency of using library positively }\end{array}$ & 2.5 & .94 & Accepted \\
\hline
\end{tabular}


In the table above, the researchers examined the perceived influence of exposure to information on library services on library users. The users were asked to identify the influence that their exposure to information on library services will have on them. The results of the study as presented in the table above suggests that all the items were accepted as the perceived influence of the promotion of library service through social media on users.

\section{Discussion of Findings}

In this study, the researchers examined the use of social media for the purposes of promoting library services in Nigeria. Library professionals and users took part in the study. In doing so, specific attention was paid to use of social media to promote library services, objectives of using social media for promoting library services, strategies for using social media for promoting library services, challenges to the use of social media to promote library services as well as perceived influence of the use of social media for promoting library services on users. It was found that there is low extent of use of social media for promoting library services. What this means is that library professionals have so far paid less attention in using social media to promote library services in Nigeria. This is not a cheering outcome because social media platforms are very popular among most people, especially people of school age typically will utilize library services most. The result of this study also revealed seven objectives for the use of social media to promote library services. These are: to create awareness on library services; to educate users on library services; to encourage patronage of library services; to meet 21st century library users at their door steps; to satisfy the need of library users; to outsmart competitors and to meet up with the demand of the 21 st century library services. The result of this study is similar to that of Patil and Pradhan (2014) who note that the overall aim of the library is the promotion of patronage. The departing point between their (Patil \& Pradhan, 2014) results and the current study is that they did not examine how social media could be used to promote library services. It was also found that the strategies for using social media to promote library services include: creating dedicated social media accounts on library services; embedding information on library services into the accounts of users; using multiple social media accounts like Facebook, YouTube, Twitter; Using pictures in social media messages on library services; Using videos to explain certain aspects of library services; frequently updating social media messages on library services and Providing 24 hours 7 days prompt response from users. The result of this study is contrary to those of Ju (2006), Adeloye (2003), Bhat (1998) who examined strategies for promoting library services and reported the use of other approaches other than social media. We also found that the application of social media for the purposes of promoting library services has been faced with a number of challenges. The result, however, support the views of other scholars (Hinchliffe \& Leon, 2011; Moulaison and Corrado, 2011; Yi, 2014) who admitted that the new media world has substantially impacted on library practice and services.

The challenges are: lack of skilful manpower; in adequate finance; lack of interest on the part of library management; lack of appropriate and up to date tool; inadequate staff members and lack of a conducive working environment. These results suggest that for social media to be fully utilized for the purposes of promoting library services, certain things need to be done. In other words, this aspect of the results have implications on how to effectively utilize social media to promote library services. It means that for social media to be effectively applied to promote library services, certain administrative steps must be taken. The results regarding the perceived influence of social media on the promotion of library services revealed that: exposure to information on library services on social media will influence the image of libraries positively; exposure to information on library services on social media will influence my attitudes towards libraries positively; exposure to information on library services on social media will influence my use of libraries positively; exposure to information on library services on social media will influence and educate users on library services; exposure to information on library services on social media will influence my competence in using library services and exposure to information on library services on social media will influence frequency of using library positively. This aspect of the findings makes a strong case for the application of social media to promote library services in Nigeria.

The results of this study have implications on library practice and scholarship. Regarding library practice, the results suggests that to effectively promote library services with a corresponding possibility for increased patronage, there is the need for management of libraries to address serious issues of inadequate manpower, lack of facilities and poor funding. When this is done, it is hoped that social media could be fully applied for the purposes of promoting library services in Nigeria. In terms of scholarship, the results of the study has added to the body of literature regarding the important role that social media platforms are now playing in different spheres of the society. In particular, the results has added to studies on the role of social media in library services. It is therefore, recommended that library management should put in place programs and policies that support the use of social media to promote library services. It is also recommended that libraries should develop and implement plan of actions on how to apply social media in the promotion of library services. Finally, further studies should explore the efforts made by library managements in using social media to promote library services.

\section{Acknowledgements}

We are deeply appreciative of librarians and users who agreed to take part in this study. Without them, this study may not have been conducted.

\section{REFERENCES}

Adeloye, A. (2003). How to market yourself and your library organization: a solo librarian's guide. The Bottom Line, 16(1), 1518. DOI: https://doi.org/10.1108/08880450310464018 (In English)

Ashcroft, L. (2002). Issues in developing, managing and marketing electronic journals collections. Collection Building, 21(4), 147-154. DOI: https://doi.org/10.1108/01604950210447386 (In English)

Bhat, M. I. (1998). Marketing of library and information services at British Council library network in India. DESIDOC Bulletin of Information Technology, 18(3), 29-33. Retrieved from https:// publications.drdo.gov.in/ojs/index.php/djlit/article/download/3398/ 1829/ (In English)

Cummings, S. (1994). Marketing and promotion of information products. Quarterly Bulletin of the International Association of Agricultural Information Specialists, 39(1/2), 69-75. (In English)

de Saez, E.E. (2002). Marketing concepts for libraries and information services (2nd ed.). London: Facet Publishing. (In English)

Dodsworth, E. (1998). Marketing academic libraries: a ne- 
cessary plan. Journal of Academic Librarianship, 24(4), 320 322. (In English).

Fisher, P. H., \& Pride, M. M. (2006). Blueprint for your library marketing plan: a guide to help you survive and thrive. Chicago, IL: American Library Association. (In English)

Helinsky, Z. (2008). A short-cut to marketing the library. Oxford: Chandos Publishing. (In English)

Hinchliffe, L.J., \& Leon, R. (2011). Innovation as a framework for adopting Web 2.0 marketing approaches. In Gupta, D. \& Savard, R. (Eds.), Marketing libraries in a Web 2.0 world (pp. 58-65). Berlin: De Gruyter Saur. (In English)

Jackson, M. (2001). Marketing the HyLife project. Library Management, 22(1/2), 43-49. DOI: https://doi.org/10.1108/ 01435120110358853 (In English)

Ju, W. (2006). Marketing and service promotion practices in the LCAS. Library Management, 27(6/7), 336-343. DOI: https:// doi.org/10.1108/01435120610702323 (In English)

Kaplan, A. M., \& Haenlein, M. (2010). Users of the world, unite! The challenges and opportunities of social media. Business Horizons, 53 (1), 59-68. DOI: https://doi.org/10.1016/j.bushor.2009.09.003 (In English)

Mathews, B. (2009). Marketing today's academic library: a bold new approach to communicating with students. Chicago, IL: American Library Association. (In English)

Mathews, P. \& George, S. (2013). Growth and future of social media. International Journal of Advanced Research in Computer Engineering \& Technology. 2 (12), 3177-3183. Retrieved from http://ijarcet.org/wp-content/uploads/IJARCET-VOL-2-ISSUE-123177-3183.pdf (In English)

Mitra, M. (2016). Promoting library services in the digital era among the children and young adults. Retrieved from https:// www.ifla.org/node/10518 (In English)

Nkanga, N. A. (2002). Marketing information services in Botswana: an exploratory study of selected information providing institutions in Gaborone. Library Management, 23(6/7), 302-313. DOI: https://doi.org/10.1108/01435120210432273 (In English)

Nwazor, J. C., \& Godwin-Maduike, C. C. (2015). Social media and academic performance of business education students in South-East Nigeria. Journal of Education and Practice, 6(25), 127-134. Retrieved from https://www.iiste.org/Journals/index.php/ JEP/article/view/25698 (In English)

Patil, S. K., \& Pradhan, P. (2014). Library promotion practices and marketing of Library services: A role of Library professionals. Procedia - Social and Behavioral Sciences, 133, 249-254. Retrieved from https://core.ac.uk/download/pdf/82182409.pdf (In English)

Potter, N. (2012). The library marketing toolkit. London: Facet Publishing. Retrieved from http://dlib.scu.ac.ir/bitstream/Hannan/ 464474/2/9781856048064.pdf (In English)

Rowley, J. (2003). Information marketing: seven questions. Library Management, 24(1/2), 13-19. DOI: https://doi.org/10.1108/ 01435120310454476 (In English)

Walther, J. B., \& Parks, M. R. (2002). Cues filtered out, cues filtered in: Computer-mediated communication and relationships. In M. L. Knapp, \& J. A. Daly (Eds.), Handbook of interpersonal communication (pp. 529-563). Thousand Oaks, CA: Sage. (In English)

Webreck, T. \& Alman, S. (2007). Crash course in marketing for libraries. Westport, CT: Libraries Unlimited. (In English)

Welch, L. (2006). The other 51 weeks: a marketing handbook for librarians. Wagga Wagga, NSW, Australia: Centre for Information Studies, Charles Sturt University. (In English)

Yi, Z. (2014). Australian academic librarians' perceptions of effective Web 2.0 tools used to market services and resources. The Journal of Academic Librarianship, 40(3/4), 220-227. (In English)

\section{LIST OF REFERENCE LINKS}

Adeloye A. How to market yourself and your library organization: a solo librarian's guide. The Bottom Line. 2003. 16(1). 15-18. DOI: https://doi.org/10.1108/08880450310464018

Ashcroft L. Issues in developing, managing and marketing electronic journals collections. Collection Building. 2002. 21(4). 147-154. DOI: https://doi.org/10.1108/01604950210447386

Bhat M. I. Marketing of library and information services at British Council library network in India. DESIDOC Bulletin of Information Technology. 1998. 18(3). 29-33. URL https:// publications.drdo.gov.in/ojs/index.php/djlit/article/download/3398/ 1829/

Cummings S. Marketing and promotion of information products. Quarterly Bulletin of the International Association of Agricultural Information Specialists. 1994. 39(1/2). 69-75.

de Saez E. E. Marketing concepts for libraries and information services (2nd ed.). London: Facet Publishing, 2002.

Dodsworth E. Marketing academic libraries: a necessary plan. Journal of Academic Librarianship. 1998. 24(4). 320-322.

Fisher P. H. \& Pride M. M. Blueprint for your library marketing plan: a guide to help you survive and thrive. Chicago, IL: American Library Association, 2006.

Helinsky Z. A short-cut to marketing the library. Oxford: Chandos Publishing, 2008.

Hinchliffe L. J. \& Leon R. Innovation as a framework for adopting Web 2.0 marketing approaches. In: Marketing libraries in a Web 2.0 world / D. Gupta \& R. Savard (Eds.). Berlin: De Gruyter Saur, 2011. Pp. 58-65.

Jackson M. Marketing the HyLife project. Library Management. 2001. 22(1/2). 43-49. DOI: https://doi.org/10.1108/ 01435120110358853

Ju W. Marketing and service promotion practices in the LCAS. Library Management. 2006. 27(6/7). 336-343. DOI: https://doi.org/ $10.1108 / 01435120610702323$

Kaplan A. M. \& Haenlein M. Users of the world, unite! The challenges and opportunities of social media. Business Horizons. 2010. 53 (1). 59-68. DOI: https://doi.org/10.1016/j.bushor.2009.09.003

Mathews B. Marketing today's academic library: a bold new approach to communicating with students. Chicago, IL: American Library Association, 2009.

Mathews P. \& George S. Growth and future of social media. International Journal of Advanced Research in Computer Engineering \& Technology. 2013. 2 (12), 3177-3183. URL http:// ijarcet.org/wp-content/uploads/IJARCET-VOL-2-ISSUE-12-31773183.pdf

Mitra M. Promoting library services in the digital era among the children and young adults. 2016. URL https://www.ifla.org/node/ 10518

Nkanga N. A. Marketing information services in Botswana: an exploratory study of selected information providing institutions in Gaborone. Library Management. 2002. 23(6/7). 302-313. DOI: https://doi.org/10.1108/01435120210432273

Nwazor J. C. \& Godwin-Maduike C. C. Social media and academic performance of business education students in SouthEast Nigeria. Journal of Education and Practice. 2015. 6(25). 127-134. URL https://www.iiste.org/Journals/index.php/JEP/ article/view/25698.

Patil S. K. \& Pradhan P. Library promotion practices and marketing of Library services: A role of Library professionals. Procedia - Social and Behavioral Sciences. 2014. 133. 249-254. URL https://core.ac.uk/download/pdf/82182409.pdf

Potter N. The library marketing toolkit. London: Facet Publishing, 2012. URL http://dlib.scu.ac.ir/bitstream/Hannan/464474/2/ 9781856048064.pdf

Rowley J. Information marketing: seven questions. Library Management. 2003. 24(1/2). 13-19. DOI: https://doi.org/10.1108/ 01435120310454476 
Walther J. B. \& Parks M. R. Cues filtered out, cues filtered in: Computer-mediated communication and relationships. In: Handbook of interpersonal communication / Knapp M. L. \& Daly J. A. (Eds.). Thousand Oaks, CA: Sage, 2002. Pp. 529-563.

Webreck T. \& Alman S. Crash course in marketing for libraries. Westport, CT: Libraries Unlimited, 2007.
Welch L. The other 51 weeks: a marketing handbook for librarians. Wagga Wagga, NSW, Australia: Centre for Information Studies, Charles Sturt University, 2006.

Yi Z. Australian academic librarians' perceptions of effective Web 2.0 tools used to market services and resources. The Journal of Academic Librarianship. 2014. 40(3/4). 220-227.

Хадрон К. Карі,

Федеральний університет Otиoke (Байєлса, Нігерія)

e-mail: karih@fuotuoke.edu.ng, ORCID 0000-0001-7475-5172

Гбойсга К. Ойеран,

Федеральний університет Otиoke (Байєлса, Нігерія)

e-mail: karih@fuotuoke.edu.ng, ORCID0000-0003-0333-8202

\section{ПРОСУВАННЯ БІБЛІОТЕЧНИХ ПОСЛУГВ ЕПОХУ СОЦІАЛЬНИХ МЕДІА: ДОСЛІДЖЕННЯ ВИКОРИСТАННЯ, ЦІЛЕЙ, ПРОБЛЕМ ТА СПРИЙНЯТОГО ВПЛИВУ}

Соціальні медіа значно змінили кожну частину нашого буття. Вони змінили форму і характер спілкування. До появи платформ соціальних медіа переважали референтні форми спілкування, оскільки відстань була суттєвим бар'єром у спілкуванні, але це змінилося 3 появою соціальних мереж. Ці зміни стосуються галузі освіти в цілому та бібліотечної справи зокрема. Якщо раніше послуги надавалися лише у бібліотечних залах, то тепер бібліотекою можна скористатися дистанційно. Читачі мають нові очікування від управління бібліотеками. Вони бажають отримувати послуги оперативніше та технологічніше, ніж раніше. Ці зміни привертають увагу дослідників до питань, пов'язаних зі змінами, що відбулися в управлінні бібліотеками в епоху соціальних медіа. У даній статті було розглянуто використання опосередкованих платформ для підвищення обізнаності щодо послуг у бібліотеках Нігерії. Дослідження передбачало досягнення п'яти основних цілей. В якості дизайну дослідження було використано описове опитування. Для дослідження були відібрані як бібліотекарі $(n=300)$, так і користувачі бібліотеки $(n=300)$. Інструментарієм для збору даних $є$ спеціально розроблена анкета. Для дослідження використовували описовий аналіз, як прості відсотки, середнє та стандартне відхилення. Було встановлено, що використання соціальних медіа є низьким у цілях підвищення обізнаності громадськості про послуги в бібліотеках. Також було окреслено сім цілей застосування соціальних медіа для підвищення обізнаності про послуги в бібліотеках. Було також повідомлено про сім стратегій використання соціальних медіа для просування бібліотечних послуг. Повідомлялося також про перешкоди на шляху використання соціальних медіа для просування бібліотечних послуг, а саме: відсутність кваліфікованих кадрів; брак фінансування; відсутність інтересу з боку управління бібліотекою; відсутність сучасного оснащення; неадекватний персонал та відсутність сприятливого робочого середовища. Також показано роль соціальних медіа-повідомлень у розвитку бібліотечних послуг. Результати проведеного аналізу можуть втілюватися у практиці функціонування бібліотек та обумовлювати специфіку подальших досліджень. Що стосується бібліотечної практики, то для ефективного просування бібліотечних послуг із відповідною можливістю посилення меценатства існує необхідність в управлінні бібліотеками для вирішення серйозної проблеми недостатньої кількості робочої сили, браку відповідного матеріального забезпечення та недостатнього фінансування. Коли це буде зроблено, можна сподіватися, що соціальні медіа можуть бути повністю застосовані для просування бібліотечних послуг у Нігерії. Щодо теоретичної складової запропонованого аналізу, результати дослідження продемонстрували важливу роль, яку зараз відіграють платформи соціальних медіа в різних сферах суспільства. Зокрема, акцентується увага на ролі соціальних медіа у бібліотечних послугах. Тому рекомендується, щоб в управління бібліотеками було запроваджено програми та політику, які підтримують використання соціальних медіа для просування бібліотечних послуг.

Ключові слова: бібліотечні послуги; професіонал; просування; сочіальні медіа; користувачі.

(c) Kari Hudron K., Oyeniran Gboyega K.

Надійшла до редакції: 04.09.2019

Прийнята до друку: 23.09.2019 